'home' local education authority to undertake the entire responsibility for assessment, and the working party points out that administration of this system of assessment would be simplified by adoption of a uniform standard boarding fee at all training colleges.

The total additional cost of these proposals, over and above the present annual expenditure on grants for personal expenses of $£ 510,000$, is estimated at about $£ 1,400,000$, of which $£ 892,000$ would fall on the Exchequer and $£ 508,000$ on local rates. The financial arrangements for teacher training as a whole would be simplified, and the working party also suggests including in the one pattern the personal and dependant's grants paid by the Ministry to some older one-year students, and also grants to day students towards the cost of their home keep while attending college, thus bringing the annual expenditure covered by the proposals to about $£ 2,080,000$.

\section{BARLEY ROOTS: NITROGEN ASSIMILATION AND RESPIRATION}

T has already been shown that the respiration of I barley seedlings is closely dependent on the supply of nitrogenous nutrients. In culture solutions containing ammonium salts or nitrates, barley seedlings show a rapid increase in carbon dioxide production, this boing initially largely confined to the root system. The relation between respiration and the assimilation of nitrogen by roots has now been more fully explored by A. J. Willis and E. W. Yemm (New Phytol., 54, 2, 163; 1955). These investigators have presented and discussed a considerable series of observations and have reached the following conclusions.

The assimilation of nitrogen in excised roots of barley leads to high rates of respiration. The greatest respiratory increases are shown by roots deficient in nitrogen and rich in carbohydrate. Roots cut from seedlings which are grown under conditions of nitrogen deficiency and which have not exhausted their endosperm reserves show smaller carbon dioxide increases when external sources of nitrogen are supplied than roots from older seedlings. Increases in both earbon dioxide production and oxygen uptake result from treatment of roots with ammonium salts, nitrates, nitrites and hydroxylamine, although there are secondary toxic effects of hydroxylamine. The form of the respiratory response depends upon the source of nitrogen supplied: ammonium salts give rise to very rapid increases in gaseous exchanges, while with nitrate the greatest increases are not shown until about $9 \mathrm{hr}$. after its addition to the roots. The effects of other anions and cations supplied with the nitrogen source are small. At very low concentrations of the nitrogen supply the respiratory increase is limited, and all the available nitrogen is exhausted from the culture solution.

These effects of nitrogen compounds on respiration are different in form and magnitude from salt respiration. The salt respiration of roots grown under the conditions used here has been demonstrated to be very much smaller than the respiratory increases found on supplying the roots with inorganic nitrogen. Measurements of respiratory quotients and evidence from direct analysis indicate that nitrogen is rapidly metabolized in the roots, and that high rates of respiration are associated with the synthesis of nitrogen compounds in the tissues.

\section{THE EFFECT OF CERTAIN DRYING CONDITIONS ON THE PUTREFACTION OF CATTLE HIDES AND GOATSKINS}

$T$ is unfortunately true that, after flaying, African prepared hides and skins are left lying in heaps for an unnecessarily long time in wet and filthy conditions, and it is not surprising-that putrefactive damage forms one of the more common blemishes of East African hides and skins.

Putrefactive damage can be diminished by measures which will decrease the bacterial population. One of the most effective ways of preserving hides and skins is to reduce their moisture-content to a level where bacterial action and growth become impossible. Air-drying is the most commonly used method of preservation in East Africa because $(a)$ it is a quick, cheap and easy method for African conditions, (b) chemicals are not generally available for salting or pickling, (c) transport charges on dried hides and skins are lower than on salted or pickled stock, and $(d)$ no special storage or transport facilities are required.

A series of experiments was carried out by Dr. R. L. Sykes to determine the extent to which putrefaction could be controlled by certain methods of drying (Colonial Plant and Animal Products, 4, No. 3 ; 1954).

The traditional local African method of air-drying is to peg hides and skins on the ground, flesh-side up, to dry in the sun. The products, which in the past were called 'sun-drieds' and are now known as 'grounddrieds', are dirty, unattractive articles shumned by most tanners because, not only are they difficult to handle and soak back, but also because they give rise to unpredictable and serious losses during processing. Up to twenty-five years ago the bulk of East African hides and skins were prepared in this manner; but, as the result of tests on drying procedures carried out by a few pioneers, certain tanners realized that, when dried in sheds, the resulting 'shade-drieds' possessed superior leather-producing values and gave significantly lower tannery losses. The difference was so outstanding that controlled tests were earried out in 1932 by the Imperial Institute and the Kenya Veterinary Department. These experiments confirmed the earlier tannery observations, and as a result the drying of hides and skins in open-sided sheds after suspension within a vertical rectangular frame was advocated.

From its 1932 tests the Imperial Institute drew the important conolusion that the essential factor in air-drying was suspension and not shade.

The 1932 trials also led the Imperial Institute to suggest that hides could be dried in the open provided the heat from the meridian sun could be tempered by orientating the plane of the hides in an east-to. west direction and by inclining it to the vertical so that the plane lay parallel to the rays of the midday sun.

It was not always easy to make uneducated producers understand what was required, and, since the midday sun in East African latitudes strikes a vertical plane obliquely, it was found more practicable to advocate vertical frames when drying hides in the open.

Neither this experimental evidence, nor the fact that many Uganda hides are so satisfactorily dried in the open in the wet season that tanners cannot 